\title{
Feeding a Formula Supplemented With Long Chain Polyunsaturated Fatty Acids Modifies the "Ex Vivo" Cytokine Responses to Food Proteins in Infants at Low Risk for Allergy
}

\author{
CATHERINE J. FIELD, JOHN E. VAN AERDE, LINDSAY E. ROBINSON, AND M. THOMAS CLANDININ
}

\begin{abstract}
Department of Agricultural, Food and Nutritional Science [C.J.F., M.T.C.], Department of Medicine [C.J.F., M.T.C.], and Department of Pediatrics [J.E.A.], University of Alberta, Edmonton, Alberta, Canada T6G 2P5; Department of Human Health and Nutritional Sciences [L.E.R.], University of Guelph, Guelph, Ontario, Canada N1G 2W1
\end{abstract}

\begin{abstract}
Long chain polyunsaturates (LCP) status during the early neonatal period is associated with a reduced risk of atopic symptoms and later allergies. In this study, we characterized the immune response of low-risk, term, formula-fed infants randomized at $\leq 14 \mathrm{~d}$ of age to standard term formula (Formula) or formula containing LCP (Formula+LCP) for 4 wks. Infants exclusively fed human milk were included for comparison. Peripheral blood was collected at 14 and $42 \mathrm{~d}$ of age, and lymphocyte phenotype, proliferation, and cytokine production (IL-2, IL-4, IL-6, IL-10, IL-12, IFN- $\gamma$, TNF- $\alpha$, TGF $\beta$ ) were assessed after incubation with $\beta$-lactoglobulin (BLG) and soy protein (SOY). Lymphocyte proliferation did not differ between groups. Compared with human milk-fed infants at 2 wks, formula-fed infants produced more TNF- $\alpha$ and IFN- $\gamma$ and had more cells expressing ICAM-1 (CD54) after incubation with BLG and SOY $(p<0.05)$. At 6 wks of age, infants fed Formula+LCP produced more TNF- $\alpha$ with SOY (3.2-fold) and IFN- $\gamma$ (3.3-fold) with BLG compared with infants fed Formula $(p<0.05)$. In conclusion, low-risk term infants fed formula before $14 \mathrm{~d}$ of age produced more TNF- $\alpha$ and IFN- $\gamma$ in response to food proteins. Feeding Formula+LCP for 4 wks maintained the higher TNF- $\alpha$ and IFN- $\gamma$ response to these food proteins. (Pediatr Res 64: 411-417, 2008)
\end{abstract}

A llergic diseases are a major health issue in infants during the first year of life (1). Exclusive feeding of human milk (HM) is associated with attenuated, or delayed, development of food allergies (2). The long chain n-3 polyunsaturated fatty acid (PUFA) composition of HM is hypothesized to contribute to the protective effects of breast-feeding against allergy (3). Supporting the importance of these long chain polyunsaturated fats (LCP) in directing appropriate development of the immune system, recent studies demonstrate that supplementation during pregnancy with n-3 PUFA reduces the prevalence of allergic symptoms in high risk children $(4,5)$.

The predominantly Th2 cytokine response, and relatively immature Th1 response, in infants has been implicated in susceptibility to atopic disorders $(6,7)$. The ability to develop tolerance to food proteins is an age-related phenomenon that occurs during the first year of life (8), a time when many changes occur in immune function (9-11). Most infants successfully develop tol-

Received February 7, 2008; accepted May 14, 2008.

Correspondence: Catherine J. Field, Ph.D., RD, Department of Agricultural, Food and Nutritional Science, University of Alberta, 4-126A HRIF East, Edmonton, Alberta, Canada T6G 2E1; e-mail: catherine.field@ualberta.ca

Supported by funding from Wyeth Nutritionals International and MTI Meta Tech Inc. erance to food antigens; however, in a small minority, some food antigens provoke adverse symptoms, defined as intolerance or allergy. Relatively little is known about the development of tolerance but it is critical to our understanding of atopic disease. Epidemiologic data suggest that infants not exclusively breastfed are at higher risk of developing allergies $(12,13)$, implicating a role of early diet in the development of tolerance. It is hypothesized that an imbalance between n-6 PUFA and n-3 PUFA and an insufficient cellular level of arachidonic acid (AA) may alter thymic $\mathrm{T}$ cell development and the balance of Th1 and Th2 cytokines, thus affecting the ability to develop tolerance (14). At the time the epidemiologic studies on early feeding and atopic disease were conducted, commercial infant formula was not supplemented with the LCP, AA, and docosahexaenoic acid (DHA). Our work in preterm infants has demonstrated that adding DHA and AA to a standard preterm formula is associated with a $\mathrm{T}$ cell maturity and ability to produce cytokines in response to mitogenic stimulation that is more similar to breast-fed infants (15). A better understanding of both the effect of not feeding HM and the role of LCP supplementation in early life (before allergic responses are established) on the ability of the immune system to respond appropriately to potential food allergens is needed. Understanding the immune processes that contribute to tolerance will help us to recognize and manage infants at risk. The current study compared the ex vivo response of peripheral blood cells with two common food proteins in full term infants at low risk for allergy fed a standard formula with or without LCP. We specifically measured immune cell phenotypes and the ability of peripheral blood cells to proliferate and produce cytokines in vitro in response to $\beta$-lactoglobulin (BLG) and soy proteins (SOY). An age-matched group of infants exclusively fed HM was included for comparison. 


\section{METHODS}

Subjects. Mothers (from the Regional Program for Newborn Services, Edmonton, Alberta, Canada) who had chosen to switch from breastfeeding to feeding their infants with commercial formula before $14 \mathrm{~d}$ of age were approached to enter the study. All infants had received some HM before entering the study. Consenting mothers $(n=30)$ were randomized to receive either a standard term infant formula (Formula; $n=14$ ) or the same formula supplemented with AA (20:4n-6) and DHA (22:6n-3) (Formula+LCP; $n=$ 16). Mothers and investigators were blinded to the formula received. A group of infants who were exclusively fed HM (HM, $n=16)$ from birth were included for comparison. Laboratory staff were blinded to all groups. Inclusion criteria for all infants stipulated that by $14 \mathrm{~d}$ of age infants were receiving $100 \%$ of their intake by mouth from HM or commercial infant formula and that infants were healthy with birth weight, length, and head circumference between the 10th and 90th percentile for gestational age, according to the National Center for Health Statistics growth charts (16). Infants with major congenital malformations, documented systemic or congenital infection, significant neonatal morbidity, diagnosed maternal autoimmune disorders, acute illness precluding oral feedings, or conditions requiring infant feedings other than standard formula or HM were excluded. None of the infants had received corticosteroids, red cell or plasma transfusions, or i.v. lipid emulsions before entering the study. Infants were enrolled into the study between 7 and $14 \mathrm{~d}$ of age. The first blood sample was collected before infants consumed the experimental formula (7-14 d) and was designated as 2 wks of age. The average age of entry into the study ( $2 \mathrm{wk}$ blood sample collected) was $11.8 \pm$ $2.2 \mathrm{~d}$ for the HM, $10.2 \pm 3.0 \mathrm{~d}$ for the Formula, and $9.7 \pm 2.8 \mathrm{~d}$ for the Formula + LCP groups. The formula-fed infants had been fed one of several commercially available infant formulas (none of which contained LCP) before randomization to their assigned study formula. Sex distribution and gestational age of infants in each group are presented in Table 1. Infants were confirmed as low-risk for allergy, based on a negative family history and a milk challenge that was administered at 16 wks of age. Briefly, at 16 wks, when all infants in this study were still exclusively fed one of the formula or breast milk, each infant was fed $125 \mathrm{~mL}$ of cow's milk. They were monitored by their mothers for $24 \mathrm{~h}$ and then examined by a neonatologist. All infants tolerated the milk feeding without any clinical signs of intolerance.

Diet treatments. The commercial formulas used were S-26 (Wyeth Nutrition, Philadelphia, PA) and S-26 Gold (Wyeth Nutrition, Philadelphia, PA). The only difference between the two formulas was the addition of AA (20:4n-6 at $0.34 \% \mathrm{wt} / \mathrm{wt})$ and DHA $(22: 6 \mathrm{n}-3$ at $0.2 \% \mathrm{wt} / \mathrm{wt})$ from single cell triglycerides (Martek Biosciences Corp, Baltimore, MD) to the S-26 Gold. The complete fatty acid composition of the two formulas has been previously reported (17).

Table 1. Infant weight, length, and head circumference at 2 wk and 6 wk of age in the different dietary groups

\begin{tabular}{|c|c|c|c|}
\hline Variable & $\begin{array}{c}\text { HM } \\
(n=16)\end{array}$ & $\begin{array}{l}\text { Formula } \\
(n=14)\end{array}$ & $\begin{array}{c}\text { Formula }+\mathrm{LCP} \\
\quad(n=16)\end{array}$ \\
\hline Gender (M:F) & $6: 10$ & $3: 11$ & $7: 9$ \\
\hline Gestational age at birth (wk) & $39 \pm 1^{*}$ & $39 \pm 2$ & $40 \pm 1$ \\
\hline \multicolumn{4}{|l|}{ Weight $(\mathrm{g})$} \\
\hline Birth & $3690 \pm 536$ & $3508 \pm 696$ & $3638 \pm 595$ \\
\hline $2 \mathrm{wk}$ & $3814 \pm 464$ & $3628 \pm 598$ & $3774 \pm 570$ \\
\hline $6 \mathrm{wk}$ & $5045 \pm 516 \dagger$ & $4901 \pm 590 \dagger$ & $5076 \pm 646 \dagger$ \\
\hline \multicolumn{4}{|l|}{ Weight gain $(\mathrm{g})$} \\
\hline $2-6 w k$ & $1231 \pm 321$ & $1273 \pm 344$ & $1302 \pm 362$ \\
\hline \multicolumn{4}{|l|}{ Length $(\mathrm{cm})$} \\
\hline Birth & $52 \pm 3$ & $51 \pm 3$ & $51 \pm 2$ \\
\hline $2 \mathrm{wk}$ & $53 \pm 2 \ddagger$ & $51 \pm 2$ & $52 \pm 2$ \\
\hline $6 \mathrm{wk}$ & $58 \pm 3 \dagger$ & $56 \pm 2 \dagger$ & $56 \pm 2 \dagger$ \\
\hline \multicolumn{4}{|l|}{ Head circumference $(\mathrm{cm})$} \\
\hline Birth & $35.0 \pm 1.6$ & $34.8 \pm 1.9$ & $35.2 \pm 1.3$ \\
\hline $2 \mathrm{wk}$ & $36.6 \pm 1.1$ & $35.9 \pm 1.4$ & $36.1 \pm 1.0$ \\
\hline $6 \mathrm{wk}$ & $38.9 \pm 1.2 \dagger$ & $38.6 \pm 1.1 \dagger$ & $38.4 \pm 1.4 \dagger$ \\
\hline
\end{tabular}

* Values are means \pm standard deviation for human milk fed (HM), unsupplemented infant formula (Formula) and infant formula supplemented with long-chain polyunsaturated fatty acids (Formula +LCP).

$\dagger$ Within a group, mean value at 6 wks of age is significantly $(p<0.001)$ different from the mean value at 2 wks of age.

$\$$ Value is significantly different from the Formula value at 2 wks $(p<$ $0.05)$.
Ethical considerations. This study was approved by the Research Ethics Committee of the Faculty of Medicine, University of Alberta, and the Special Services and Research Committee of the Capital Health Authority, Edmonton, Alberta. Informed written consent was obtained from one parent of each infant participating in the study.

Study population, anthropometric, and blood measures. Infant weight $(\mathrm{g})$, length $(\mathrm{cm})$, and head circumference $(\mathrm{cm})$ was measured at study entry (designated as $2 \mathrm{wks}$ ) and after 4 wks in the study (designated as 6 wks of age). A $2-\mathrm{mL}$ blood sample was drawn by venipuncture from each infant at study entry and after 4 wks of feeding ( $42 \pm 4 \mathrm{~d}$ of age). Assessment of standard blood chemistry, hematological measures, and plasma phospholipid composition has been reported (17).

Estimation of lymphocyte proliferation to food proteins. Lymphocytes were isolated from whole blood as previously described $(15,17)$. Proliferation was estimated by ${ }^{3} \mathrm{H}$-thymidine uptake as per Field et al. (17). Briefly, lymphocytes $\left(1 \times 10^{6}\right.$ cells $\left./ \mathrm{mL}\right)$ were cultured for $120 \mathrm{~h}$ in 96 -well micro-titer plates with or without either BLG $(980 \mu \mathrm{g} / \mathrm{mL}$, Sigma Chemical Company, St. Louis, MO), a soy protein with a significantly reduced isoflavone content (SOY, $643 \mu \mathrm{g} / \mathrm{mL}$, Wyeth Nutrition, Philadelphia, PA), or a slightly hydrolyzed soy protein isolate with normal levels of isoflavones (HSOY, 624 $\mu \mathrm{g} / \mathrm{mL}$, Wyeth Nutrition, Philadelphia, PA). The two different SOY proteins selected for the study have been previously used in the formulation of infant formula. Preliminary studies confirmed that the maximum rate of ${ }^{3} \mathrm{H}$ thymidine uptake for these proteins at these concentrations was achieved by $120 \mathrm{~h}$ (data not shown). Eighteen hours before harvesting the cells, each well was pulsed with $1 \mu \mathrm{Ci}$ of ${ }^{3} \mathrm{H}$-thymidine (Amersham/Pharmacia Biotech, Montreal, PQ) and analyzed as previously described (17). All assays were performed in triplicate and stimulation indices were calculated for each condition as: the amount of ${ }^{3} \mathrm{H}$-thymidine (dpm) incorporated by cells in the presence of the protein divided by the amount of ${ }^{3} \mathrm{H}$-thymidine (dpm) incorporated by cells incubated in the absence of the protein.

Cytokine production by cultured peripheral blood cells. Cytokine production from isolated lymphocytes $\left(1 \times 10^{6}\right.$ cells $)$, stimulated with either BLG $(980 \mu \mathrm{g} / \mathrm{mL})$ or SOY $(643 \mu \mathrm{g} / \mathrm{mL})$ for $120 \mathrm{~h}$, was measured as previously described (17). As no difference was found in the proliferative response to the two different SOY proteins, the soy protein that has been used most frequently in infant formula (i.e., SOY, with a significantly reduced isoflavone content) was used for the cytokine assays. Cells exposed to BLG or SOY were saved for phenotyping (see below). Supernatants were collected and stored at $-70{ }^{\circ} \mathrm{C}$ for cytokine analysis. The concentrations of IL-2, IL-4, IL-6, IL-10, IL-12, IFN- $\gamma$, TNF- $\alpha$, and TGF- $\beta$ were determined using ELISA kits as per Field et al. (17).

Phenotyping of mononuclear lymphocytes postculture. Cells were phenotyped postculture in an attempt to identify cell types that may have become activated by exposure to food proteins. Immune cell phenotypes were identified by immunofluorescence techniques (15). The following additional mAbs prelabeled with FITC, phycoerythrin (PE), or biotin (B) (purchased from Sigma Chemical Company, St. Louis MO or BD Pharmingen, Mississauga, ON) were used: CD54-PE (ICAM-1), CD80-B (B cell subset costimulatory signal to $\mathrm{T}$ cells), CD16-FITC (natural killer cells and macrophages), CD11c-PE ( $\beta_{2}$ leukocyte integrins found on monocytes, granulocytes, and macrophages), and CD11b-B (granulocytes, monocytes, natural killer cells, and macrophages). Cells were labeled and acquired as described (15). Analysis (1,000-10,000 cells per mAb combination) was performed on the gated lymphocyte population (15). Appropriate isotype controls (Sigma Chemical Co.) were used for each labeled MAb and resultant percentages were corrected for each subject's background fluorescence $(<1 \%)$.

Statistical analysis. Based on an earlier feeding study of preterm infants (15), the sample size for each group was deemed sufficient to establish statistical differences in IL-2 production after PHA stimulation. As the $2 \mathrm{wk}$ (baseline) value was collected before the infants were randomized to the two formula groups, we anticipated, and later confirmed, that there were no statistical differences in baseline measures among the formula fed infants. These infants (exposed to some infant formula) were then combined for comparison to infants exclusively fed $\mathrm{HM}$ at 2 wks of age. Differences between diet and age (including changes between 2 and $6 \mathrm{wks}$ ) were identified using a mixed model repeated measures analysis of variance (18) and significant differences between groups identified by least square means. For those measures that were not normally distributed, data were log transformed (and normal distribution confirmed) before statistical analysis. All statistical analyses were performed using SAS (Version 8, SAS Institute, Cary, NC). Unless otherwise indicated, results are presented as means \pm standard deviations (SD). 


\section{RESULTS}

Anthropometric measures. There were no differences among groups (presented as total group \pm SD) at 2 and 6 wks of age in body weight, length, or head circumference (Table 1). Blood chemistry concentrations and white blood cell concentrations and differentials did not differ between groups at either 2 or 6 wks of age and were within reference ranges for healthy infants (17).

PUFA concentration of plasma phospholipids. The plasma phospholipid composition of the infants in this study has been previously reported in detail (17). Briefly, at 6 wks of age, plasma concentrations of linoleic acid (18:2n-6) among infants fed the Formula $(169 \pm 38, n=14)$ or Formula + LCP $(160 \pm 44, n=15)$ were higher $(p<0.05)$ than in HM-infants (125 $\pm 43, n=16)$. The concentration of DHA (22:6n-3) was higher $(p<0.05)$ among infants fed Formula +LCP $(21 \pm 12$, $n=15)$ than infants fed Formula $(11 \pm 6, n=14)$ but not HM $(15 \pm 8, n=16)$. There were no differences among groups in the concentrations of linolenic acid (18:3n-3), AA (20:4n-6), or eicosapentaenoic acid (20:5n-3) (17).

Lymphocyte proliferation in the absence and presence of food proteins. The absolute rate of ${ }^{3} \mathrm{H}$-thymidine uptake by lymphocytes incubated in the absence (Fig. 1A) or presence (data not illustrated) of food proteins did not differ significantly among groups at either 2 or 6 wks of age. However,
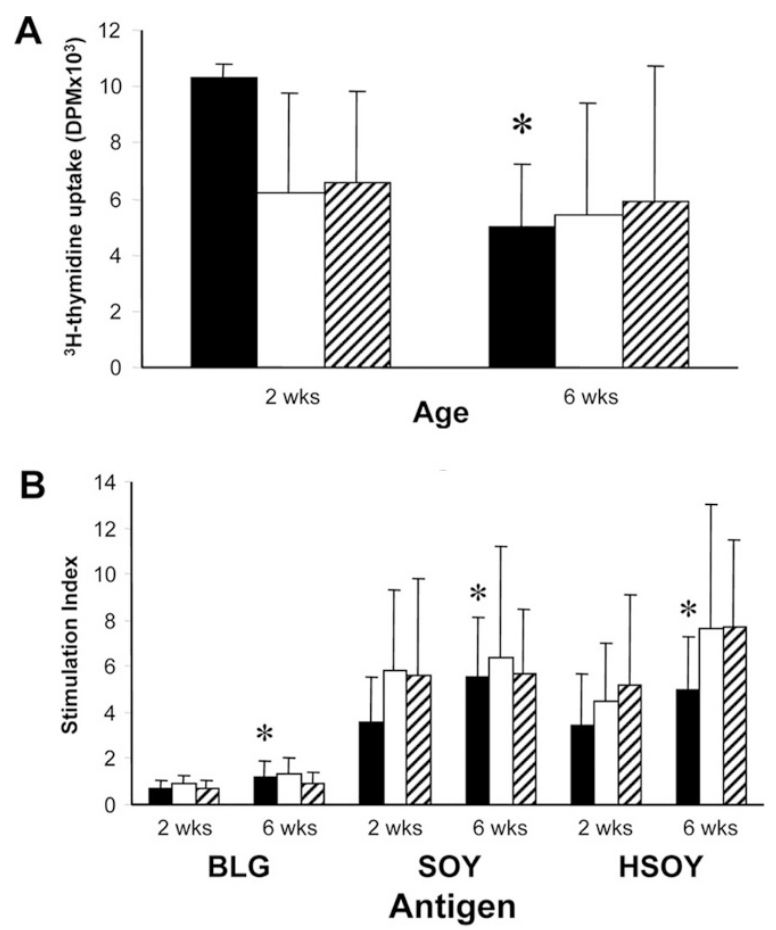

Figure 1. Mean response $\pm \mathrm{SD}$ of peripheral blood cells from infants fed HM (black bars; $n=14$ ), Formula (white bars; $n=13$ ), or Formula+LCP (cross-hatched bars; $n=14$ ). A, Amount of ${ }^{3} \mathrm{H}$-thymidine incorporated during the last $18 \mathrm{~h}$ of a $120 \mathrm{~h}$ culture without stimuli. $B$, Stimulation Index: ${ }^{3} \mathrm{H}$-thymidine (dpm) incorporated by cells in the presence of antigen $/{ }^{3} \mathrm{H}$ thymidine (dpm) incorporated by cells in the absence of antigen, calculated during the last $18 \mathrm{~h}$ of a $120 \mathrm{~h}$ culture with BLG, SOY, or HSOY. Within a culture condition, for each diet group * indicates a significant difference from the 2 wk value $(p<0.05)$. At any age, there was no statistical difference in the rate of ${ }^{3} \mathrm{H}$-thymidine uptake among diet groups. among HM-infants, proliferation of lymphocytes cultured without added protein decreased $(p<0.005$; Fig. 1A) between 2 and 6 wks. This resulted in a significant increase $(p<0.005)$ in the stimulation index between 2 and 6 wks to all three food proteins by HM-infants (Fig. 1B). The absolute rate of ${ }^{3} \mathrm{H}$-thymidine uptake increased significantly in response to all three food proteins between 2 and 6 wks for the HM-infants but not those fed the infant formula (data not illustrated).

Cytokine response and phenotypes present after incubation with BLG. After incubation with BLG, there was no detectable production of IL-2, IL-4, IL-12, or TGF- $\beta$ from any group. Compared with HM-infants, cells from infants exposed to formula produced significantly more TNF- $\alpha$ and IFN- $\gamma$ when stimulated with BLG at 2 wks (Table 2). With age, the amount of IL-6, IL-10, and TNF- $\alpha$ (not significant for the Formula $+\mathrm{LCP}$ ) produced in response to BLG decreased ( $p<$ $0.05)$ for all groups. At 6 wks of age, infants fed Formula + LCP produced significantly more TNF- $\alpha$ and IFN- $\gamma$ than HM-infants and significantly more IFN- $\gamma$ than the Formula group (Table 2). At 2 wks of age, infants exposed to formula, compared with HM-infants, had a higher proportion of $\mathrm{CD}^{+}$and $\mathrm{CD} 54^{+}$cells after culture with BLG and a small but significantly lower proportion of $\mathrm{CD} 20^{+} \mathrm{CD} 80^{+}$and $\mathrm{CD} 16^{+} \mathrm{CD} 11 \mathrm{c}^{+}$cells (Table 3). Compared with HM, the higher proportion of $\mathrm{CD} 54^{+}$cells was also present in both formula groups at 6 wks of age after incubation with BLG. The Formula+LCP group, compared with HM-infants, had a lower proportion $(p<0.05)$ of total B cells $\left(\mathrm{CD} 20^{+}\right)$and B cells expressing CD80 at 6 wks after BLG incubation. There was no detectable production of IL-2, IFN- $\gamma$, IL-4, IL-6, IL-10, IL-12, or TGF- $\beta$ by unstimulated cells from any of the diet groups after $120 \mathrm{~h}$ in culture.

Cytokine response and phenotypes present after incubation with SOY. There was a higher production of $\mathrm{TNF} \alpha$, IFN $\gamma$, and IL- 6 produced by cells from infants exposed to formula by 2 wks of age (Table 4). IL-6 production after incubation with SOY decreased significantly $(p<0.05)$ between 2 and 6 wks by cells from both formula groups, however, the rate of production of IL- 6 and TNF $\alpha$ by cells from the Formula +LCP group was higher $(p<0.05)$ than that of the Formula group (Table 4). There was a large interindividual variation in IFN- $\gamma$ production at 6 wks of age in all groups after SOY incubation and the mean production of this cytokine was not different among groups. At 2 wks of age, infants exposed to formula had a higher proportion of $\mathrm{CD}^{+}$cells and fewer total $\mathrm{B}$ cells $\left(\mathrm{CD} 20^{+}\right)$and $\mathrm{B}$ cells that expressed CD54 after exposure to SOY (Table 5). Although the proportion of $\mathrm{CD}^{+}$cells at 6 wks increased for all groups, the proportion present after SOY incubation was higher than HM for both formula groups. At 6 wks, the proportion of $\mathrm{B}$ cells and $\mathrm{CD} 54^{+}$cells remained significantly lower $(p<0.05)$ in SOY-exposed cultures from Formula+LCP compared with HM-infants. At $6 \mathrm{wks}$, infants fed Formula had significantly fewer $\mathrm{CD} 80^{+}$cells than HM-infants after SOY exposure. 
Table 2. Cytokine production after $120 \mathrm{~h}$ incubation with BLG by peripheral blood mononuclear cells from infants fed different diets*

\begin{tabular}{|c|c|c|c|c|}
\hline Cytokine & Age (wk) & HM & Formula & Formula $+\mathrm{LCP}$ \\
\hline IL-6 (ng/mL) & 2 & $42 \pm 20(14) \dagger$ & \multicolumn{2}{|c|}{$55 \pm 27(27)$} \\
\hline \multirow{3}{*}{ IL-10 (pg/mL) } & 6 & $22 \pm 13(15) \ddagger$ & $37 \pm 18(12) \ddagger, \S$ & $31 \pm 18(14) \ddagger$ \\
\hline & 2 & $239 \pm 161(15)$ & \multicolumn{2}{|c|}{$276 \pm 178(27)$} \\
\hline & 6 & $132 \pm 125(14) \ddagger$ & $181 \pm 141(14) \ddagger$ & $199 \pm 153(15) \ddagger$ \\
\hline \multirow[t]{2}{*}{$\mathrm{TNF}-\alpha(\mathrm{pg} / \mathrm{mL}) \|$} & 2 & $658 \pm 255(14)$ & \multicolumn{2}{|c|}{$916 \pm 440(25) \S$} \\
\hline & 6 & $329 \pm 195(13) \ddagger$ & $579 \pm 423(13) \ddagger$ & $636 \pm 381(13) \S$ \\
\hline \multirow[t]{2}{*}{$\mathrm{IFN}-\gamma(\mathrm{pg} / \mathrm{mL}) \|$} & 2 & $9.0 \pm 16(16)$ & \multicolumn{2}{|c|}{$61 \pm 137(29) \S$} \\
\hline & 6 & $19 \pm 32(15)$ & $17 \pm 20(14) \mathbb{d}$ & $56 \pm 82(15) \S$ \\
\hline
\end{tabular}

\footnotetext{
* There was no detectable production of IL-2, IL-4, IL-12 or TGF- $\beta$ after incubation with BLG.

$\dagger$ Values are means \pm standard deviation (number of infants in each group).

$\$$ Within a group, mean value at 6 wks of age is significantly $(p<0.05)$ different from the mean value at 2 wks of age.

$\S$ Within each time point, value is significantly different from the HM value $(p<0.05)$.

\| Means were log transformed prior to analysis.

II Value is significantly different from the Formula + LCP value at 6 wks $(p<0.05)$.
}

Table 3. Postculture peripheral blood cell phenotypes after stimulation with BLG by dietary group from infants fed different diets at 2 and 6 wk of age*

\begin{tabular}{|c|c|c|c|c|}
\hline Immune cell phenotype & Age (wk) & HM & Formula & Formula $+\mathrm{LCP}$ \\
\hline & & \multicolumn{3}{|c|}{$\%$ Total cells remaining in culture } \\
\hline \multirow[t]{2}{*}{$\mathrm{CD} 4^{+}$} & 2 & $48 \pm 14(16) \dagger$ & \multicolumn{2}{|c|}{$44 \pm 13(28)$} \\
\hline & 6 & $46 \pm 14(14)$ & $43 \pm 12(14)$ & $52 \pm 15(15)$ \\
\hline \multirow[t]{2}{*}{$\mathrm{CD}^{+}$} & 2 & $22 \pm 7(13)$ & \multicolumn{2}{|c|}{$37 \pm 12(28) \ddagger$} \\
\hline & 6 & $25 \pm 9(13) \S$ & $33 \pm 12(14)$ & $32 \pm 12(15) \S$ \\
\hline \multirow[t]{2}{*}{$\mathrm{CD} 20^{+}$} & 2 & $14 \pm 10(16)$ & \multicolumn{2}{|c|}{$12 \pm 7(28)$} \\
\hline & 6 & $19 \pm 11(15)$ & $14 \pm 6(14)$ & $10 \pm 5(14) \ddagger$ \\
\hline \multirow[t]{2}{*}{$\mathrm{CD} 20^{+} \mathrm{CD} 80^{+}$} & 2 & $3.1 \pm 2.2(16)$ & \multicolumn{2}{|c|}{$1.7 \pm 1.4(27) \neq$} \\
\hline & 6 & $2.6 \pm 2.6(13)$ & $1.4 \pm 1.6(14)$ & $1.1 \pm 1.5(15) \ddagger, \S$ \\
\hline \multirow[t]{2}{*}{$\mathrm{CD}_{16}{ }^{+}$} & 2 & $6.5 \pm 3.9(14)$ & \multicolumn{2}{|c|}{$7.3 \pm 5.2(28)$} \\
\hline & 6 & $4.5 \pm 2.5(14) \S$ & $3.7 \pm 2.8(13) \S$ & $4.6 \pm 2.3(15)$ \\
\hline \multirow[t]{2}{*}{$\mathrm{CD} 16^{+} \mathrm{CD} 11 \mathrm{C}^{+}$} & 2 & $3.6 \pm 3.0(15)$ & \multicolumn{2}{|c|}{$2.3 \pm 1.9(28) \neq$} \\
\hline & 6 & $1.6 \pm 1.2(15) \S$ & $1.2 \pm 1.0(14) \S$ & $1.5 \pm 0.9(15)$ \\
\hline \multirow[t]{2}{*}{$\mathrm{CD}_{16}{ }^{+} \mathrm{CD} 11 \mathrm{~B}^{+}$} & 2 & $2.6 \pm 2.2(15)$ & \multicolumn{2}{|c|}{$3.5 \pm 3.9(27)$} \\
\hline & 6 & $0.8 \pm 0.7(15) \S$ & $1.4 \pm 1.4(14)$ & $1.5 \pm 1.1(15) \S$ \\
\hline \multirow[t]{2}{*}{$\mathrm{CD}_{1} 4^{+}$} & 2 & $3.0 \pm 3.0(16)$ & \multicolumn{2}{|c|}{$2.9 \pm 2.0(25)$} \\
\hline & 6 & $1.5 \pm 1.5(14)$ & $1.6 \pm 2.2(14)$ & $0.9 \pm 0.8(15) \S$ \\
\hline \multirow{2}{*}{$\mathrm{CD} 4^{+}$} & 2 & $61 \pm 23(16)$ & \multicolumn{2}{|c|}{$82 \pm 14(25) 末$} \\
\hline & 6 & $70 \pm 18(15)$ & $82 \pm 15(14) \ddagger$ & $88 \pm 7(13) \ddagger$ \\
\hline
\end{tabular}

* There were no differences in the following cell types poststimulation between ages or among diet groups. The percent positive cells remaining in culture at 6 wks of age were: $\mathrm{CD}^{+} 0^{+}(14 \pm 16 \%, n=45), \mathrm{CD}_{11 \mathrm{~B}}^{+}(9.3 \pm 13 \%, n=47), \mathrm{CD}_{11 \mathrm{C}^{+}}(5.1 \pm 5.6 \%, n=47), \mathrm{CD} 20^{+} \mathrm{CD} 54^{+}(13 \pm 7 \%, n=46)$.

$\dagger$ Values are means \pm standard deviation (number of infants in each group).

\$ Within each time point, value is significantly different from the HM value $(p<0.05)$.

$\S$ Within a group, mean value at 6 wks of age is significantly different $(p<0.05)$ from the mean value at 2 wks of age.

\section{DISCUSSION}

During the first 6 wks of life, replacing HM with infant formula and varying the content of LCP in the formula influenced the ex vivo response to two food proteins (Table 6). Our study confirms that immune cells from low-risk infants, without a demonstrated allergy to milk or family history of allergy, respond to food proteins by producing IL-6, IL-10, TNF- $\alpha$, and IFN- $\gamma$. IL-4 was not detectable after incubation with either protein, suggesting that a classic Th2 response was not produced by polymorphonuclear cells in infants in response to food proteins. The predominant Th1 response suggests that in low-risk infants, stimulation with food proteins may promote an antigen-specific $\mathrm{IgG}$ response as opposed to a Th2 response, which would more likely stimulate eosinophils, mast cells, and an IgE type response (19).

Although there is considerable evidence that cytokines are involved in immunologic responses and allergy (20), data on cytokine production to food proteins by immune cells from healthy infants are limited. Compared with HM-infants at 2 wks of age, cells from formula-fed infants produced significantly more Th1 cytokines (greater than 1.5-fold the amount of TNF- $\alpha$ and greater than 5 -fold the amount of IFN- $\gamma$ ) when incubated with BLG or SOY. We previously reported that the formula-fed infants have a higher proportion of $\mathrm{CD}^{+}$cells (particularly $\mathrm{CD} 4{ }^{+} \mathrm{CD} 28^{+}$cells) and a lower proportion of CD14 ${ }^{+}$cells, compared with those exclusively fed HM (17). This may have contributed to the higher Th1 response after exposure to food proteins, but the small difference we previously reported is unlikely to completely account for the very large differences in cytokine production between groups. Both TNF- $\alpha$ and IFN- $\gamma$ are found in physiologically active concentrations in breast milk and are reported to escape digestion and be absorbed into the infant's immune system (21). Formulafed infants may need to produce more TNF- $\alpha$ and IFN- $\gamma$, due 
Table 4. Cytokine production after 120 h incubation with SOY by peripheral blood mononuclear cells from infants fed different diets*

\begin{tabular}{|c|c|c|c|c|}
\hline Cytokine & Age (wk) & $\mathrm{HM}$ & Formula & Formula+LCP \\
\hline \multirow[t]{2}{*}{$\mathrm{IL}-10 \dagger$} & 2 & $93 \pm 79(13) \ddagger$ & \multicolumn{2}{|c|}{$133 \pm 121(24)$} \\
\hline & 6 & $73 \pm 62(15)$ & $87 \pm 75(13)$ & $120 \pm 153(13)$ \\
\hline \multirow[t]{2}{*}{$\mathrm{IL}-2 \dagger$} & 2 & $23 \pm 16(15)$ & \multicolumn{2}{|c|}{$27 \pm 28(24)$} \\
\hline & 6 & $40 \pm 69(14)$ & $40 \pm 37(13)$ & $41 \pm 44(12)$ \\
\hline \multirow[t]{2}{*}{ IL-6 } & 2 & $23 \pm 13(14)$ & \multicolumn{2}{|c|}{$36 \pm 17(24) \S$} \\
\hline & 6 & $16 \pm 11(14)$ & $13 \pm 8(13) \|, \mathscr{T}$ & $22 \pm 13(14) \|$ \\
\hline \multirow[t]{2}{*}{ TNF- $\alpha \dagger$} & 2 & $75 \pm 47(13)$ & \multicolumn{2}{|c|}{$147 \pm 136(25) \S$} \\
\hline & 6 & $63 \pm 53(14)$ & $49 \pm 37(14) \mathbb{I}$ & $159 \pm 137(13) \S$ \\
\hline \multirow[t]{2}{*}{ IFN- $\gamma^{\dagger}$} & 2 & $57 \pm 76(12)$ & \multicolumn{2}{|c|}{$277 \pm 350(27) \S$} \\
\hline & 6 & $115 \pm 165(12)$ & $182 \pm 157(12)$ & $247 \pm 211(15)$ \\
\hline
\end{tabular}

* There was no detectable production of IL-4, IL-12 or TGF- $\beta$ after incubation with SOY.

$\dagger$ Means were $\log$ transformed prior to analysis.

$\$$ Values are means \pm standard deviation (number of infants in each group). All cytokines are presented as pg/mL with the exception of IL-6 which is expressed as $\mathrm{ng} / \mathrm{mL}$.

$\S$ Within each time point, value is significantly different from the HM value $(p<0.05)$.

$\|$ Within a group, mean value at 6 wks of age is significantly different $(p<0.05)$ from the mean value at 2 wks of age.

II Value is significantly different from the Formula+LCP value at 6 wks $(p<0.05)$.

Table 5. Postculture peripheral blood cell phenotypes after stimulation with SOY by dietary group from infants fed different diets at 2 and 6 wk of age*

\begin{tabular}{|c|c|c|c|c|}
\hline Immune cell phenotype & Age (wk) & HM & Formula & Formula+LCP \\
\hline & & \multicolumn{3}{|c|}{$\%$ Total cells remaining in culture } \\
\hline \multirow[t]{2}{*}{$\mathrm{CD}^{+}$} & 2 & $61 \pm 10(15) \dagger$ & \multicolumn{2}{|c|}{$59 \pm 14(27)$} \\
\hline & 6 & $58 \pm 11(14)$ & $53 \pm 12(13)$ & $53 \pm 17(14)$ \\
\hline \multirow[t]{2}{*}{$\mathrm{CD}^{+}$} & 2 & $20 \pm 5(14)$ & \multicolumn{2}{|c|}{$29 \pm 9(27) \ddagger$} \\
\hline & 6 & $24 \pm 5(14) \S$ & $32 \pm 9(14) \ddagger, \S$ & $30 \pm 8(14) \ddagger$ \\
\hline \multirow[t]{2}{*}{$\mathrm{CD} 20^{+}$} & 2 & $8 \pm 5(15)$ & \multicolumn{2}{|c|}{$5 \pm 2(27) \ddagger$} \\
\hline & 6 & $13 \pm 8(14) \S$ & $10 \pm 6(14) \S$ & $9 \pm 4(14) \ddagger, \S$ \\
\hline \multirow{2}{*}{$\mathrm{CD} 20^{+} \mathrm{CD} 54^{+}$} & 2 & $6.8 \pm 4.5(14)$ & \multicolumn{2}{|c|}{$4.0 \pm 2.5(24) \ddagger$} \\
\hline & 6 & $12 \pm 8.1(14) \S$ & $9.5 \pm 5.8(14) \S$ & $8.2 \pm 3.8(14) \ddagger, \S$ \\
\hline \multirow[t]{2}{*}{$\mathrm{CD}_{16}{ }^{+}$} & 2 & $5.6 \pm 4.1(15)$ & \multicolumn{2}{|c|}{$4.9 \pm 4.2(27)$} \\
\hline & 6 & $3.8 \pm 1.8(15)$ & $3.7 \pm 3.0(14)$ & $4.2 \pm 2.3(14)$ \\
\hline \multirow[t]{2}{*}{$\mathrm{CD}_{1} 4^{+}$} & 2 & $2.1 \pm 2.5(15)$ & \multicolumn{2}{|c|}{$2.4 \pm 2.3(26)$} \\
\hline & 6 & $0.9 \pm 0.8(14)$ & $1.0 \pm 1.2(14) \S$ & $1.0 \pm 1.1(14) \S$ \\
\hline \multirow[t]{2}{*}{$\mathrm{CD}_{11 C^{+}}$} & 2 & $4 \pm 3(15)$ & \multicolumn{2}{|c|}{$3.7 \pm 2.8(27)$} \\
\hline & 6 & $4 \pm 2(15)$ & $2.4 \pm 2.1(14) \S$ & $4.4 \pm 6.2(14)$ \\
\hline \multirow[t]{2}{*}{$\mathrm{CD} 80^{+}$} & 2 & $10 \pm 12(15)$ & \multicolumn{2}{|c|}{$8 \pm 9(27)$} \\
\hline & 6 & $10 \pm 11(15)$ & $3 \pm 3(14) \ddagger, \S$ & $5 \pm 8(12)$ \\
\hline
\end{tabular}

$*$ There were no differences in the following cell types poststimulation between ages or among diet groups. The percent positive cells remaining in culture at 6 wks of age were: $\mathrm{CD} 20^{+} \mathrm{CD}_{0} 0^{+}(1.4 \pm 2.2 \% n=43), \mathrm{CD} 16^{+} \mathrm{CD} 11 \mathrm{~B}^{+}(1.7 \pm 2.6 \% n=45) \mathrm{CD} 16^{+} \mathrm{CD} 11 \mathrm{C}^{+}(1.8 \pm 2.3 \% n=45), \mathrm{CD} 11 \mathrm{~B}^{+}(14 \pm 21 \%$, $n=45), \mathrm{CD}^{+} 4^{+}(82 \pm 20 \% n=43)$.

$\dagger$ Values are means \pm standard deviation (number of infants in each group).

$\$$ Within each time point, value is significantly different from the HM value $(p<0.05)$.

$\S$ Within a group, mean value at 6 wks of age is significantly different $(p<0.05)$ from the mean value at 2 wks of age.

to the absence of breast milk in their diet, to down-regulate the differentiation of dendritic cells that contribute to cow's milk allergy susceptibility (22). This hypothesis is supported in the present study by the higher production of Th1 cytokines (TNF- $\alpha$ and IFN- $\gamma$ ), without modifying proliferation of cells from formula-fed infants compared with HM-infants when incubated with BLG and SOY.

Evidence is accumulating that allergic sensitization and tolerance occur very early in life (23). Food allergies, including cow's milk allergy, are frequently the first manifestation of allergic pathology in early infancy and are the result of failure to develop oral tolerance (24). The mechanism to explain this is unknown; however, altered cytokine production in response to ex vivo protein stimulation is associated with atopic disease (25-27). IFN- $\gamma$ and TNF- $\alpha$ have a synergistic role in activating antigen presenting cells and $\mathrm{T}$ cells and in promoting oral tolerance to food antigens $(22,28)$. Allergic infants and those at risk for allergy have been shown to secrete reduced amounts of IFN- $\gamma$ and TNF- $\alpha$ when challenged with food allergens (25-27). The results of the present study suggest that formulafed infants need to produce more of these cytokines, particularly at 2 wks of age, to prevent a "proliferative" response (i.e., production of IL-2). The inability to produce sufficient IFN- $\gamma$ and TNF- $\alpha$ may contribute to the greater risk of food allergies reported in formula-fed infants $(12,13)$. Thus, our results support the hypothesis that during this early postnatal period, when allergen exposure first occurs, infants with a genetic susceptibility to allergy not receiving breast milk may be unable to produce the vigorous Th1 response needed to produce tolerance. Postculture phenotyping was performed to identify possible explanations for the differences in cytokine production. At both 2 and $6 \mathrm{wks}$ of age, immune cells from 
Table 6. Summary of the significant effects of feeding formula \pm LCP vs. human milk on infant immunity*

Effects of exposure to formula before 2 wks of age

$\uparrow$ TNF- $\alpha$ and IFN- $\gamma$ production by PBMC incubated with food proteins (BLG and SOY) and PHA

$\uparrow$ IL-6 production by PBMC incubated with SOY protein

$\uparrow \mathrm{CD}^{+} \mathrm{T}$ cells and $\mathrm{CD} 4{ }^{+} \mathrm{CD} 28^{+} \mathrm{T}$ cells among freshly isolated PBMC

$\uparrow$ Monocytes $\left(\mathrm{CD} 14^{+}\right.$cells) among freshly isolated PBMC

$\uparrow \mathrm{CD}^{+} \mathrm{T}$ cells among PBMC after incubation with PHA

$\uparrow \mathrm{CD}_{11 \mathrm{C}^{+}}$cells among PBMC after incubation with PHA

$\uparrow \mathrm{CD}^{+} \mathrm{T}$ cells among PBMC after incubation with food proteins (BLG and SOY)

$\uparrow \mathrm{CD}^{+} 4^{+}\left(\mathrm{ICAM}-1^{+}\right)$cells among PBMC after incubation with BLG

$\uparrow$ Total B cells $\left(\mathrm{CD} 20^{+}\right)$and $\mathrm{B}$ cell subsets among PBMC after incubation with food proteins (BLG and SOY)

$\uparrow \mathrm{CD}_{16}{ }^{+} \mathrm{CD} 11 \mathrm{C}^{+}$cells among PBMC after incubation with BLG

Effects of feeding a formula containing LCP from age 2 wks to 6 wks:

$\uparrow$ TNF- $\alpha$ production by PBMC incubated with PHA $v s$. unsupplemented formula-fed infants only

$\uparrow$ TNF- $\alpha$ production by PBMC incubated with SOY vs. unsupplemented formula-fed and HM-fed infants

$\uparrow$ IFN- $\gamma$ production by PBMC incubated with BLG vs. unsupplemented formula-fed and HM-fed infants

$\uparrow \mathrm{CD}^{+}{ }^{+} \mathrm{T}$ cells, $\mathrm{CD}^{+}{ }^{+} \mathrm{CD} 44^{+} \mathrm{T}$ cells and $\mathrm{CD} 4{ }^{+} \mathrm{CD} 28^{+} \mathrm{T}$ cells among freshly isolated PBMC vs. unsupplemented formula-fed infants only

$\uparrow \mathrm{CD}^{+} \mathrm{CD} 28^{+} \mathrm{T}$ cells among freshly isolated PBMC vs. unsupplemented formula-fed and HM-fed infants

$\uparrow$ total B cells $\left(\mathrm{CD} 20^{+}\right)$among freshly isolated PBMC $v s$. unsupplemented formula-fed infants only

$\uparrow \mathrm{CD}^{+} \mathrm{T}$ cells among PBMC after incubation with PHA vs. unsupplemented formula-fed infants only

* Immune results are summarized based on the findings of the current study, and those published in Field et al., 2008 (17).

PBMC, peripheral blood mononuclear cells; PHA, phytohaemagglutinin.

both formula groups, after incubation with BLG, had 35\% more cells expressing ICAM-1 (CD54), one of the key adhesion molecules with an important costimulatory role in lymphocyte activation, which is stimulated by TNF- $\alpha$. Consistent with our observation, the levels of soluble ICAM- 1 in peripheral blood were higher at 3, 6, 9, and 12 mo of age in infants who received cow's milk-based formula, compared with infants receiving hydrolyzed formula (29).

Compared with the unsupplemented formula, feeding Formula+LCP resulted in a different cytokine response to food proteins (Table 6). At 6 wks of age, production of TNF- $\alpha$ in response to SOY was 3.2-fold higher and production of IFN- $\gamma$ in response to BLG was 3.3-fold higher than production by unsupplemented formula-fed infants. The levels of both these cytokines produced by the Formula+LCP infants were significantly higher than those produced by the HM-infants. Our results suggest that the differences in these Th1 cytokines observed between formula and HM-infants at 2 wks of age remained only in formula fed infants supplemented with LCP at 6 wks of age. Although little is known about the effect of LCP on the "tolerance" response to food proteins in healthy infants, supplementation of n-3 LCP to mothers during pregnancy (5) or provision of LCP to young infants (30) is associated with reduced risk of atopic symptoms in the first year of life or the appearance of allergies later in childhood, among infants at risk of developing allergies. This has been attributed to changes in $\mathrm{T}$ cell signaling and regulating cytokine production (31). The current study suggests additional mechanisms in that LCP are also modulating T cell maturation.

Compared with HM-infants, at 2 wks formula-fed infants produced significantly more IL-6 after incubation with SOY. Compared with HM-infants, at 6 wks only the unsupplemented formula-fed infants produced more IL- 6 after incubation with BLG. IL- 6 facilitates the acute phase response and is produced by allergen-reactive Th2 cells, where it contributes to induction and maintenance of the allergic inflammatory cascade (32). Higher production of this cytokine by formulafed infants supports their higher risk of allergy, as cord blood cells from infants at high risk for developing allergy produce more IL-6 when stimulated than cells from infants at low risk (33). Although not different from HM-infants, the higher production of IL- 6 by LCP supplemented infants compared with unsupplemented infants requires further study.

To our knowledge, this study is the first to demonstrate differences in the cytokine responses to food proteins between formula and breast-fed infants during the first 2 mo of life. Four weeks of feeding an infant formula supplemented with LCP modified the cytokine response to food proteins by peripheral blood mononuclear cells. A summary of the significant effects of feeding formula with or without LCP versus feeding $\mathrm{HM}$ on infant immunity, based on these findings and our previously published results (17), is presented in Table 6 . The clinical implications of the difference in immune response between infants supplemented with and without LCP were not assessed in the current study and need to be followed up in infants genetically susceptible to developing food allergies. A better knowledge of the role of diet on the ontogeny of the immune system during the early neonatal period is useful to explain and support dietary recommendations for prevention and therapy of early atopic conditions such as food allergies that involve an imbalance of $\mathrm{T}$ cell cytokine production. The results of the present study add significantly to our understanding of the effects of early diet on the development of immune function.

Acknowledgments. The authors thank Susan Goruk for outstanding technical assistance and Bodil Larsen for her excellent skills in coordinating the clinical aspects of this study. The authors thank the significant help of Kathryn Pramuk of the Medical Affairs Department of Wyeth Nutrition in the design and execution of this study.

\section{REFERENCES}

1. Hill DJ, Hosking CS 1995 The cow milk allergy complex: overlapping disease profiles in infancy. Eur J Clin Nutr 49:S1-S12

2. Abraham CM, Ownby DR 2005 Ontogeny of the allergic inflammatory response. Immunol Allergy Clin North Am 25:215-229

3. Hoppu U, Rinne M, Lampi AM, Isolauri E 2005 Breast milk fatty acid composition is associated with development of atopic dermatitis in the infant. J Pediatr Gastroenterol Nutr 41:335-338

4. Prescott SL, Calder PC 2004 N-3 polyunsaturated fatty acids and allergic disease Curr Opin Clin Nutr Metab Care 7:123-129

5. Dunstan JA, Mori TA, Barden A, Beilin LJ, Taylor AL, Holt PG, Prescott SL 2003 Fish oil supplementation in pregnancy modifies neonatal allergen-specific immune responses and clinical outcomes in infants at high risk of atopy: a randomized, controlled trial. J Allergy Clin Immunol 112:1178-1184 
6. Prescott SL 2003 Early origins of allergic disease: a review of processes and influences during early immune development. Curr Opin Allergy Clin Immunol $3: 125-132$

7. Bjorksten B 1999 The intrauterine and postnatal environments. J Allergy Clin Immunol 104:1119-1127

8. Vaarala O, Saukkonen T, Savilahti E, Klemola T, Akerblom HK 1995 Development of immune response to cow's milk proteins in infants receiving cow's milk or hydrolyzed formula. J Allergy Clin Immunol 96:917-923

9. Wilson CB, Penix L, Weaver WM, Melvin A, Lewis DB 1992 Ontogeny of T lymphocyte function in the neonate. Am J Reprod Immunol 28:132-135

10. de Vries E, de Groot R, de Bruin-Versteeg S, Comans-Bitter WM, van Dongen JJ 1999 Analysing the developing lymphocyte system of neonates and infants. Eur J Pediatr 158:611-617

11. Holt PG, Jones CA 2000 The development of the immune system during pregnancy and early life. Allergy 55:688-697

12. van Odijk J, Kull I, Borres MP, Brandtzaeg P, Edberg U, Hanson LA, Host A, Kuitunen M, Olsen SF, Skerfving S, Sundell J, Wille S 2003 Breastfeeding and allergic disease: a multidisciplinary review of the literature (1966-2001) on the mode of early feeding in infancy and its impact on later atopic manifestations. Allergy 58:833-843

13. Host A, Halken S 2005 Primary prevention of food allergy in infants who are at risk. Curr Opin Allergy Clin Immunol 5:255-259

14. Calder PC, Miles EA 2000 Fatty acids and atopic disease. Pediatr Allergy Immunol $11: 29-36$

15. Field CJ, Thomson CA, Van Aerde JE, Parrot A, Euler AR, Clandinin MT 2000 The lower proportion of $\mathrm{CD} 45 \mathrm{RO}^{+}$cells and deficient IL-10 production by formula-fed infants, as compared to human-fed infants, is corrected with supplmentation of long chain-polyunsaturated fatty acids. J Pediatr Gastroenterol Nutr 31:291-299

16. Hamill PV, Drizd TA, Johnson CL, Reed RB, Roche AF, Moore WM 1979 Physical growth: national center for health statistics percentiles. Am J Clin Nutr 32:607-629

17. Field CJ, Van Aerde JE, Robinson LE, Thomas CM 2008 Effect of providing a formula supplemented with long-chain polyunsaturated fatty acids on immunity in full-term neonates. Br J Nutr 99:91-99

18. Wang Z, Goonewardene LA 2004 The use of MIXED models in the analysis of animal experiments with repeated measures data. Can J Anim Sci 84:1-11

19. Calder PC 2007 Immunological parameters: what do they mean? J Nutr 137:773S$780 \mathrm{~S}$
20. Singh VK, Mehrotra S, Agarwal SS 1999 The paradigm of Th1 and Th2 cytokines: its relevance to autoimmunity and allergy. Immunol Res 20:147-161

21. Field CJ 2005 The immunological components of human milk and their effect on immune development in infants. J Nutr 135:1-4

22. Jarvinen KM, Laine S, Suomalainen H 2000 Defective tumour necrosis factor-alpha production in mother's milk is related to cow's milk allergy in suckling infants. Clin Exp Allergy 30:637-643

23. Macaubas C, Prescott SL, Venaille TJ, Holt BJ, Smallacombe TB, Sly PD, Holt PG 2000 Primary sensitization to inhalant allergens. Pediatr Allergy Immunol 11:9-11

24. Strobel S, Mowat AM 2006 Oral tolerance and allergic responses to food proteins Curr Opin Allergy Clin Immunol 6:207-213

25. Suomalainen H, Soppi E, Laine S, Isolauri E 1993 Immunologic disturbances in cow's milk allergy, 2: evidence for defective interferon-gamma generation. Pediatr Allergy Immunol 4:203-207

26. Osterlund P, Jarvinen KM, Laine S, Suomalainen H 1999 Defective tumor necrosis factor-alpha production in infants with cow's milk allergy. Pediatr Allergy Immunol 10:186-190

27. Sutas Y, Hurme M, Isolauri E 1997 Oral cow milk challenge abolishes antigenspecific interferon-gamma production in the peripheral blood of children with atopic dermatitis and cow milk allergy. Clin Exp Allergy 27:277-283

28. Jung T, Moessner R, Dieckhoff K, Heidrich S, Neumann C 1999 Mechanisms of deficient interferon-gamma production in atopic diseases. Clin Exp Allergy 29:912919

29. Paronen J, Vaarala O, Savilahti E, Saukkonen T, Akerblom HK 1996 Soluble adhesion molecules and oral antigen feeding in infants. Pediatr Res 40:276-279

30. Mihrshahi S, Peat JK, Webb K, Oddy W, Marks GB, Mellis CM 2004 Effect of omega-3 fatty acid concentrations in plasma on symptoms of asthma at 18 months of age. Pediatr Allergy Immunol 15:517-522

31. Prescott SL, Irvine J, Dunstan JA, Hii C, Ferrante A 2007 Protein kinase Czeta: a novel protective neonatal $\mathrm{T}$ cell marker that can be upregulated by allergy prevention strategies. J Allergy Clin Immunol 120:200-206

32. Romagnani S 2000 The role of lymphocytes in allergic disease. J Allergy Clin Immunol 105:399-408

33. Liao SY, Liao TN, Chiang BL, Huang MS, Chen CC, Chou CC, Hsieh KH 1996 Decreased production of IFN gamma and increased production of IL- 6 by cord blood mononuclear cells of newborns with a high risk of allergy. Clin Exp Allergy 26:397-405 